ERDC/GSL TN-21-1

September 2021

\title{
ERDC \\ A Bathymetric Study of the Forebay at the Old River Low Sill Structure from 1963 to 2019
}

By Julie R. Kelley, Dr. Joseph B. Dunbar, and Dr. Maureen K. Corcoran

PURPOSE: The purpose of this study is to use historical hydrographic surveys to quantify bathymetric changes in the forebay channel area of ORLSS over the last $56 \mathrm{yr}$. The results from this comparison support an ongoing geotechnical study led by Mr. Lucas Walshire, U.S. Engineer Research and Development Center (ERDC), for the U.S. Army Corps of Engineers, New Orleans District (USACE MVN).

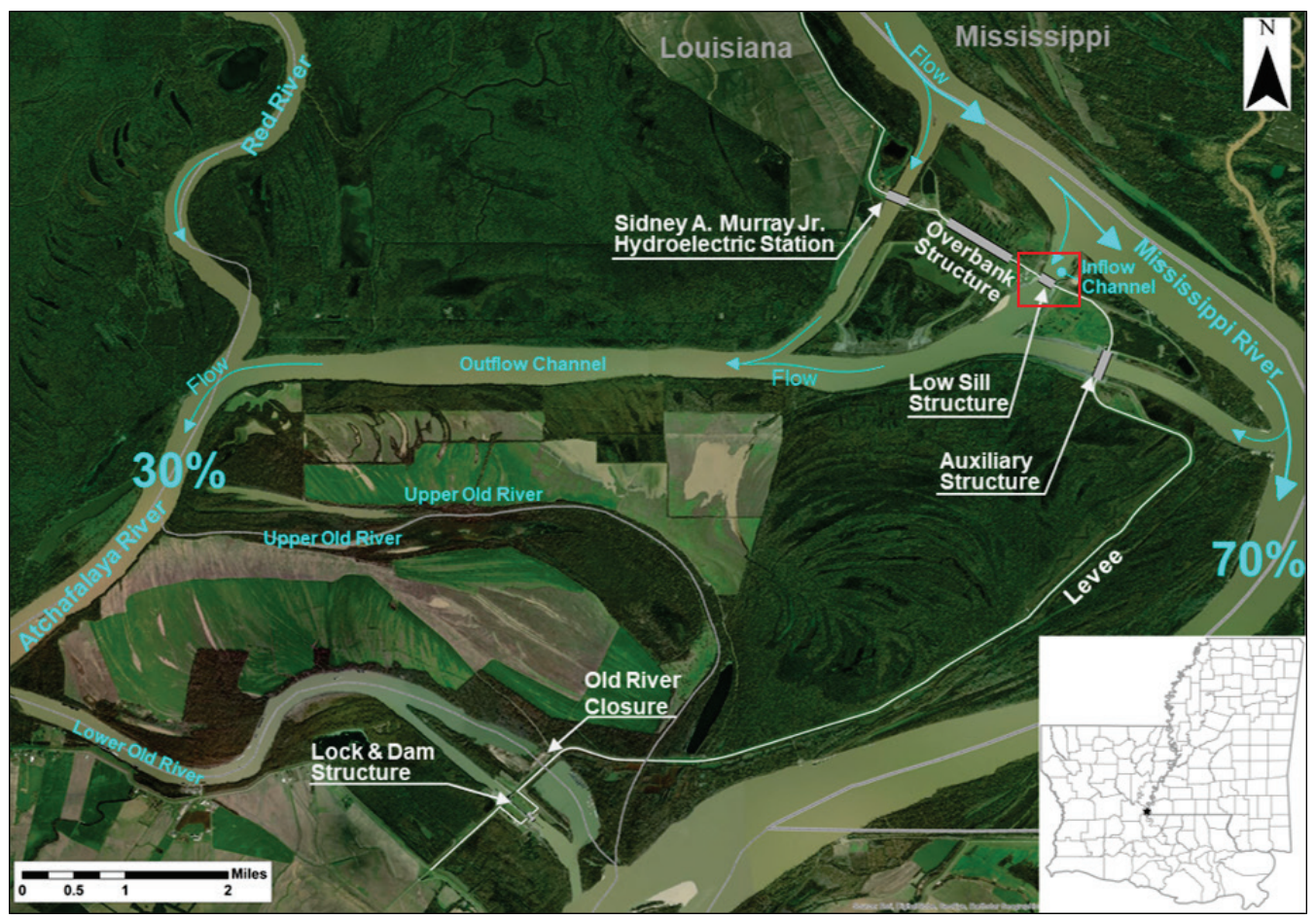

Figure 1. The Old River Low Sill Structure (in red) is part of the Old River Control Complex (modified after Heath et al. 2015).

BACKGROUND: The Old River Control Low Sill Structure (ORLSS) is in Concordia Parish, LA, at Mississippi River mile 314.5. The structure was completed in 1959 as part of the Old River Control Complex (ORCC) and was designed to prevent stream capture of the Lower Mississippi River by the Atchafalaya River (Figure 1). Along with ORLSS, the complex includes the Overbank Control Structure, Auxiliary Structure, the Sidney A. Murray Hydroelectric Station, a navigation lock, an earthen dam closing the Old River, main-line levee extensions, and bank stabilization along the Red 
and Atchafalaya rivers. The complex works to maintain a 30-percent water-flow diversion from the Mississippi River into the Atchafalaya River ${ }^{1}$.

The ORLSS was seriously damaged by a major flood on the Mississippi River in 1973. Erosion and scouring occurred in the approach channel and resulted in the failure of the wing wall at the left abutment. Deep scouring along the left abutment extended beneath the foundation, creating a void that exposed the steel piles supporting the structure (Figure 2). Emergency repairs were initiated and included the placement of rock along the left abutment where the wing wall was located. Additionally, the deep scour hole in the forebay was filled with stone, and an emergency grouting program was initiated to fill the void under the structure beneath gates 5 through 11. Repairs in 1973 and 1974 have permitted the structure to operate safely but under a flow restriction based on the stability analysis conducted after these repairs (USACE 1975a, 1975b).

HISTORICAL CHANNEL AGGRADATION: Historical channel aggradation in the main Mississippi River channel has affected the inflow discharge stage to the ORLSS structure, impacting the 22-ft flow restriction between the headwater and tail-water elevations imposed after the 1973 flood. The structure was designed with a maximum 35-ft head differential. Higher river stages have been observed at lower discharges in recent years. Increased sedimentation and channel aggradation have been attributed to the construction and operation of the Sidney A. Murray Jr. hydroelectric station (Figure 1) and the long-term geomorphic impacts associated with the cutoff program during the 1930s (Biedenharn et al. 2017; Heath et al. 2015).

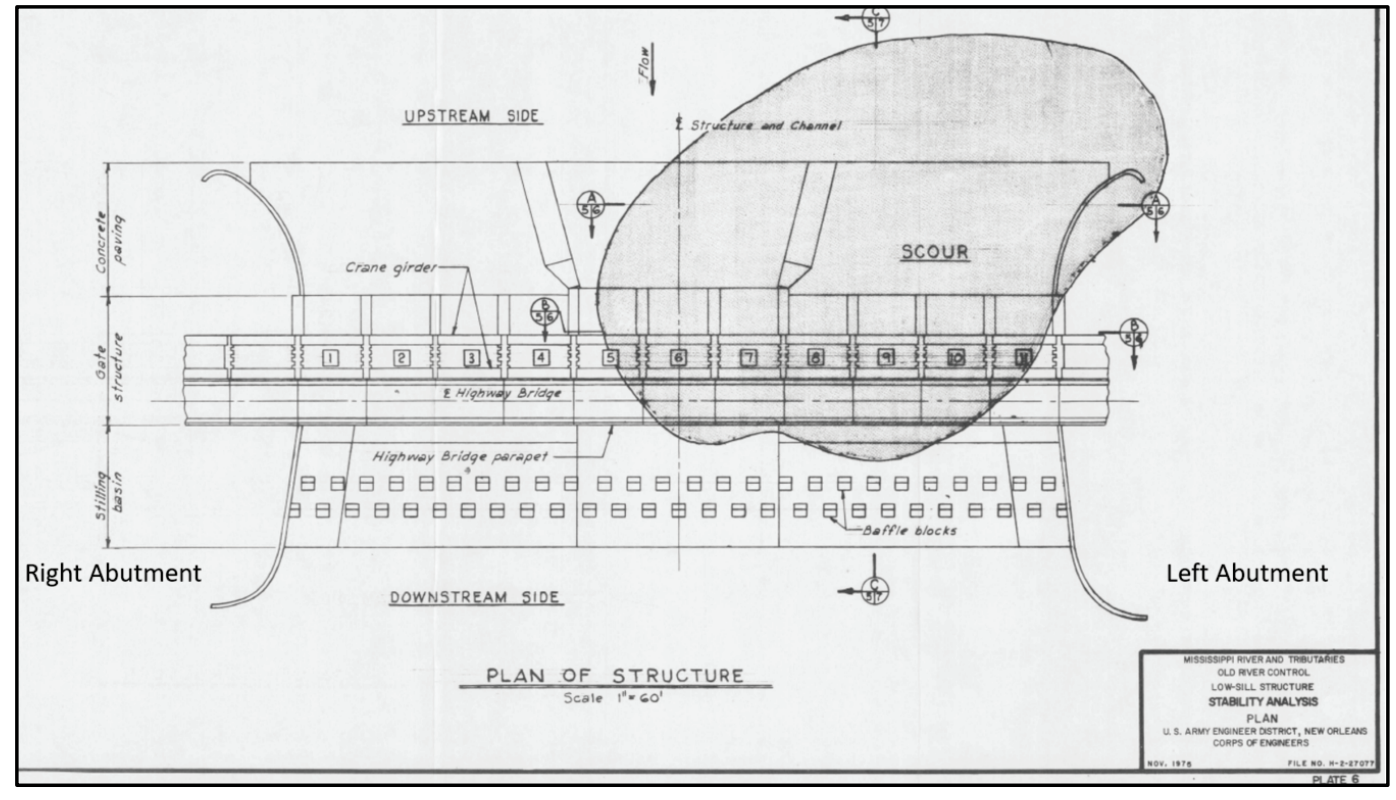

Figure 2. Scour limits under the ORLSS (USACE 1975b).

\footnotetext{
${ }^{1}$ Breland, B., L. Walshire, M.K. Corcoran, J.R. Kelley, J.E. Simms, D.W. Harrelson, and M. Zakikhani. Old River Control Complex (ORCC) Low Sill: A Literature Synthesis. In Review. U.S. Engineer Research and Development Center.
} 
Increased head differential has been a growing concern from declining channel capacity on the Mississippi River, which has resulted in higher flood stages at ORLSS. As reported by Heath et al. (2015) using a comparative cross-section plot (Figure 3), the depth of the channel thalweg at River Mile (RM) 315.5 indicates significant filling of the channel, with a decrease in overall channel depth of approximately 40 to $45 \mathrm{ft}$ between 1975 and 2008 .

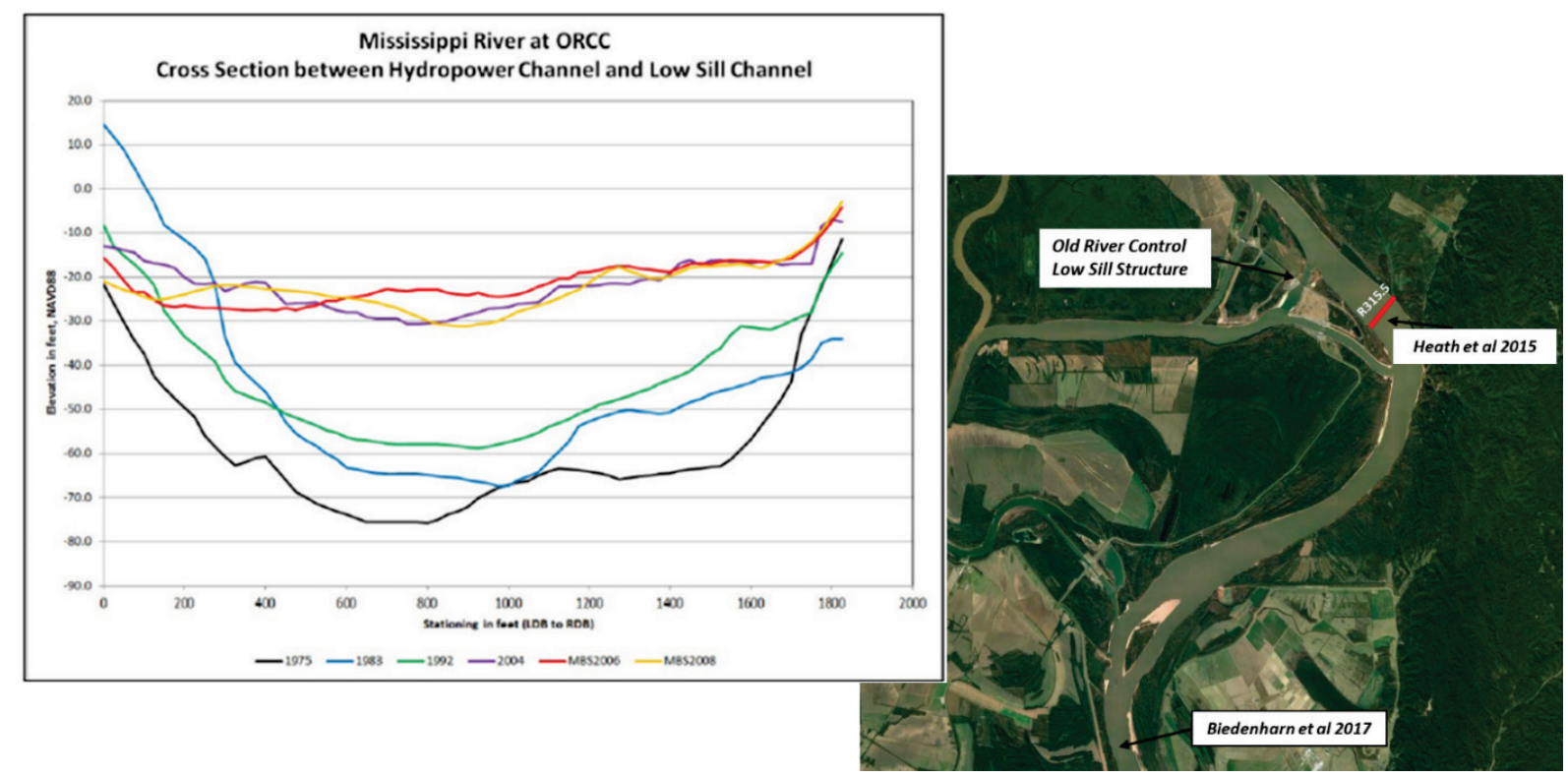

Figure 3. Comparative cross sections at RM 315.5 showing a decrease in overall channel depth between 1975 and 2008 (from Heath et al. 2015). Location of study on right.

Biedenharn et al. (2017) studied specific gage records along both the middle and lower Mississippi River to identify trends in river stages. This work was part of a geomorphic analysis using historical channel bathymetric studies, sediment load records, and substrate evolution for the Mississippi River Geomorphology and Potamology Program. Their analysis of stage and discharge relationships between Natchez, MS, and Red River Landing, LA, found an upward trend in river stages near the Old River Control Complex starting about 1975 and continuing to the present day (gage location on Figure 3). Figure 4 summarizes gage records at Red River Landing for different discharge values between 1943 and 2015. This gage is located 12 miles downstream from the ORLSS. 


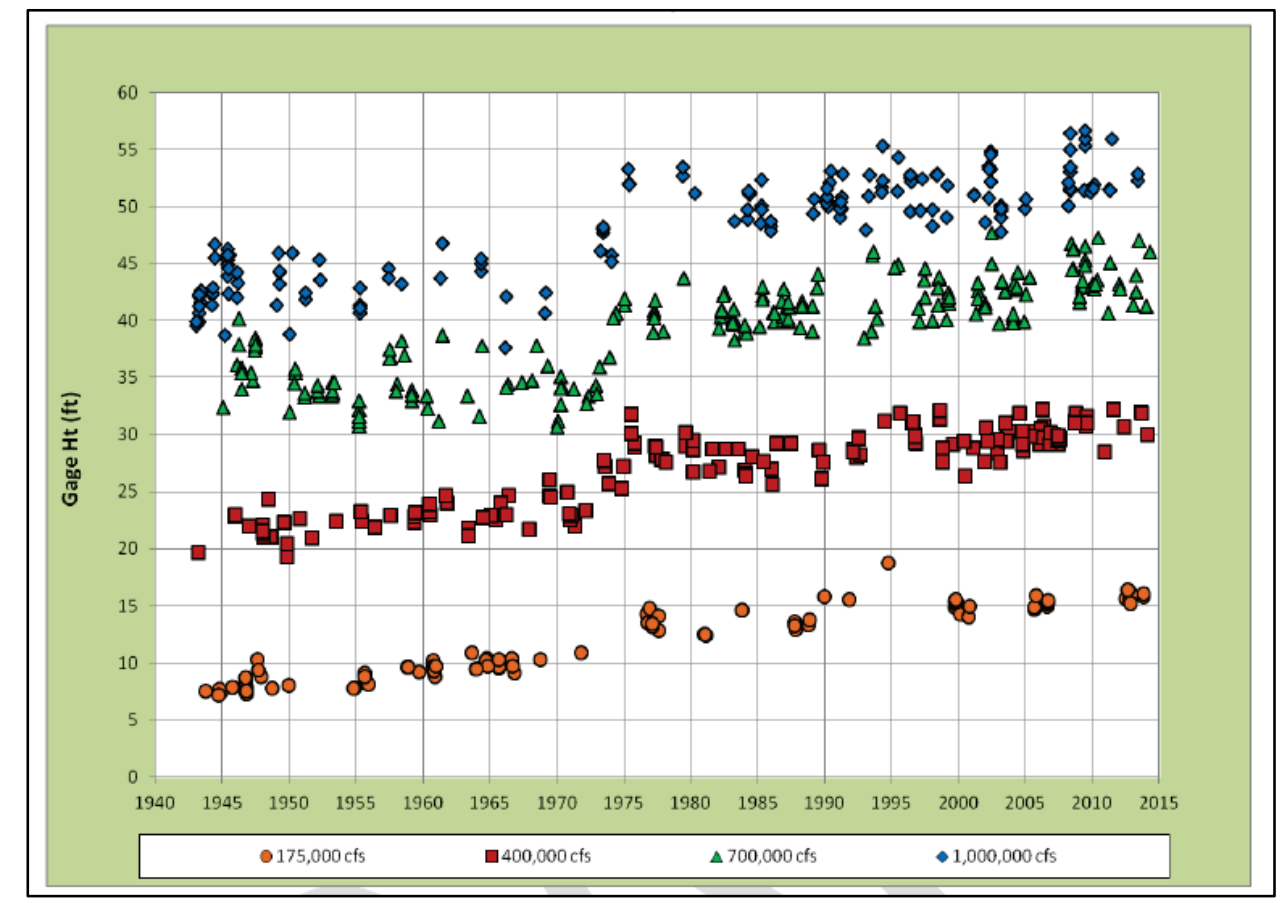

Figure 4. Red River landing gage at RM 302.4 above head of passes (AHP) (Biedenharn et al. 2017). The gage is 12 miles downstream from Old River Control Complex (location on map on Figure 3).

SCIENTIFIC METHOD: The steps used in the approach included (1) obtaining hydrographic surveys of the ORLSS forebay area in both paper and digital form, (2) georeferencing the surveys to prepare them for input in ArcMap, (3) generating profiles and channel area measurements specific to each survey, (4) comparing bathymetry changes and trends through time, and (5) preparation of a report on study findings.

HYDROGRAPHIC SURVEYS: Historically, hydrographic surveys of the Mississippi River have been completed by the USACE about every $10 \mathrm{yr}$ to provide relevant navigation information. Hydrographic surveys present a record through time of channel characteristics such as shape, width, and depth. This study will focus on the published series of atlases for the entire Lower Mississippi River that are broken into river reaches by USACE district (USACE 1965, 1976, 1985, 1993, 2004, 2013). Channel features in the ORLSS forebay area can be examined for changes related to trends in the larger Mississippi River channel around the entire ORCC.

As a side note, some focused forebay area surveys were conducted separately from the decadal mapping efforts and were part of periodic inspections completed by USACE MVN. These surveys showed more localized and intermittent changes, such as scouring. Of particular interest are the surveys from 1967, 1969, and 1971 that mention deep scour holes in the forebay prior to 1973. These surveys are referenced here for the historic record but are not included in this study. This study will focus on the decadal hydrographic surveys and larger-scale trends.

Published map surveys in paper form were not available for 1983 and 2013, but digital versions were provided by USACE MVN. The 2016 and 2019 surveys were also not available in paper map form 
and had been collected using multi-beam side-scan SONAR technology. These data were coupled with supplemental Light Detection and Ranging (LIDAR) surveys of the riverbank and were used to generate a mosaic surface raster grids of the river with bathymetry. Digital data containing range line measurements for the Mississippi River and OLSS forebay area were obtained from Mr. Charlie Little ${ }^{2}$. Additionally, Ms. Michelle Aurand ${ }^{3}$, GIS Section, USACE MVN, assisted with digital map and raster grid data from the Enterprise GIS.

Information collected for this study as paper atlas maps, digital point data, and raster images were accurately georeferenced in ArcView GIS for comparison purposes. Cross-sectional areas of selected channel locations were derived from these data. Channel-shape properties (specifically width, depth, and area) were measured and/or derived from this information.

Three survey range lines (inside red box on Figure 5) are consistent on historical hydrographic surveys in the forebay area from 1963 to 2019 . These survey range lines from south to north are R4+50, R16+50, and R21+51.1 "A." The Low Water Reference Plane (LWRP) is marked on the 1963 survey sheet in Figure 5 as dashed lines in the channel.

Elevation values are visible on the map sheets for each range line along with elevation contours. Also identified on the individual surveys are the location of revetment boundaries. The range line locations are shown on the different decadal hydrographic surveys in Figures 6 through 13 (USACE 1965, 1976, 1985, 1993, 2004, 2013). The LWRP for the respective survey years is printed on each map sheet of interest. Changes in channel area in the forebay are observable through time from the succession of hydrographic survey map sheets and digital data.

The LWRP was used with the hydrographic surveys to compare channel depths over different time periods. The LWRP is a hydraulic datum reference plane represented by a 0 - $\mathrm{ft}$ low water elevation established from long-term observations of the river's stages, discharge rates, and flow duration periods (Hunter et al. 2015). To compare depths throughout the channel, a hydraulic vertical datum, such as the LWRP, is used instead of using water surface elevations from a survey vertical datum, such as North American Vertical Datum of 1988 (NAVD 88). The LWRP provides a 0-ft reference elevation or standard to compare and track changes in the river channel through time.

\footnotetext{
${ }^{2}$ Mendrop Inc. 2019. Personal communication.

${ }^{3}$ USACE MVN. 2019. Personal communication.
} 


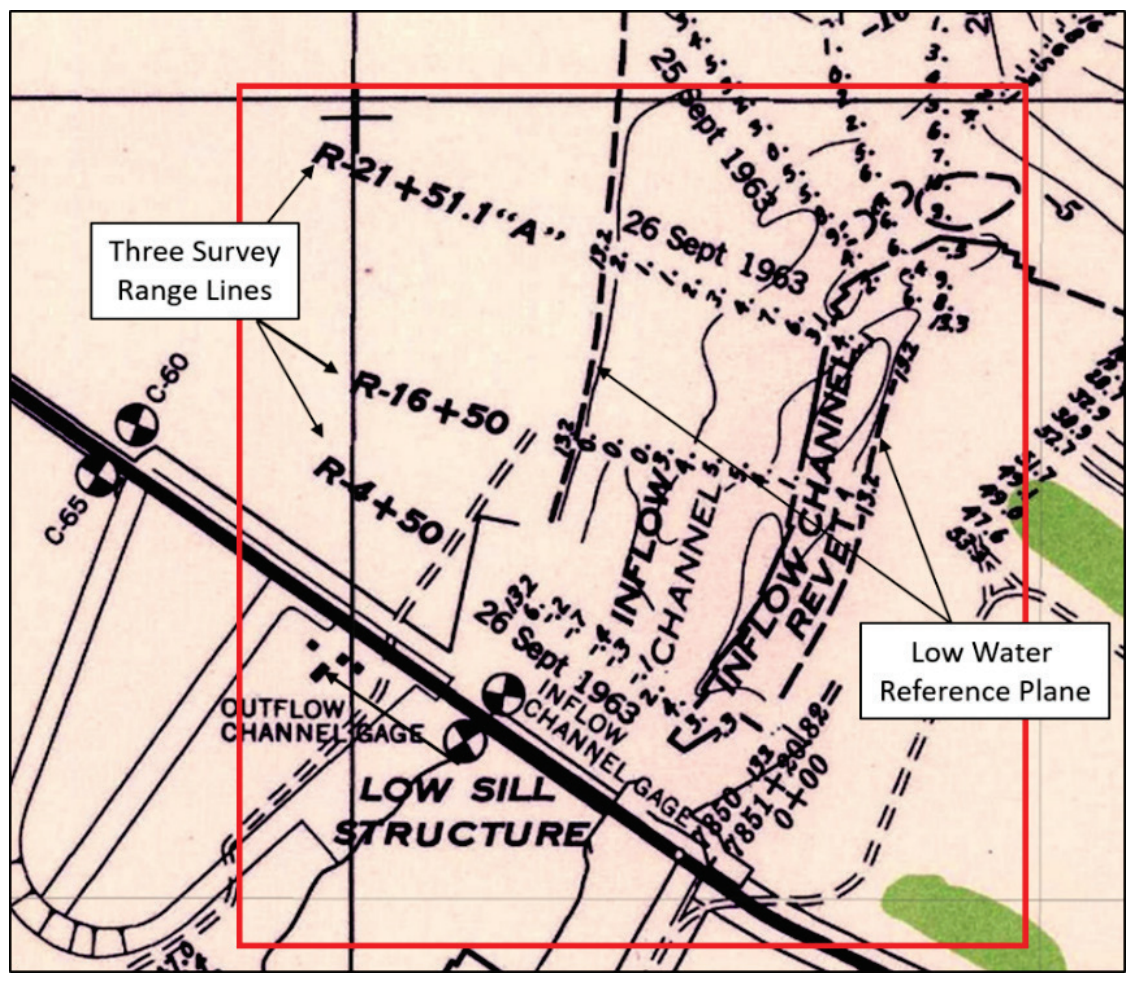

Figure 5. Three survey range lines located in the forebay area shown here on a 1963 base map (USACE 1965). The LWRP is marked on this base map with a dashed line. 


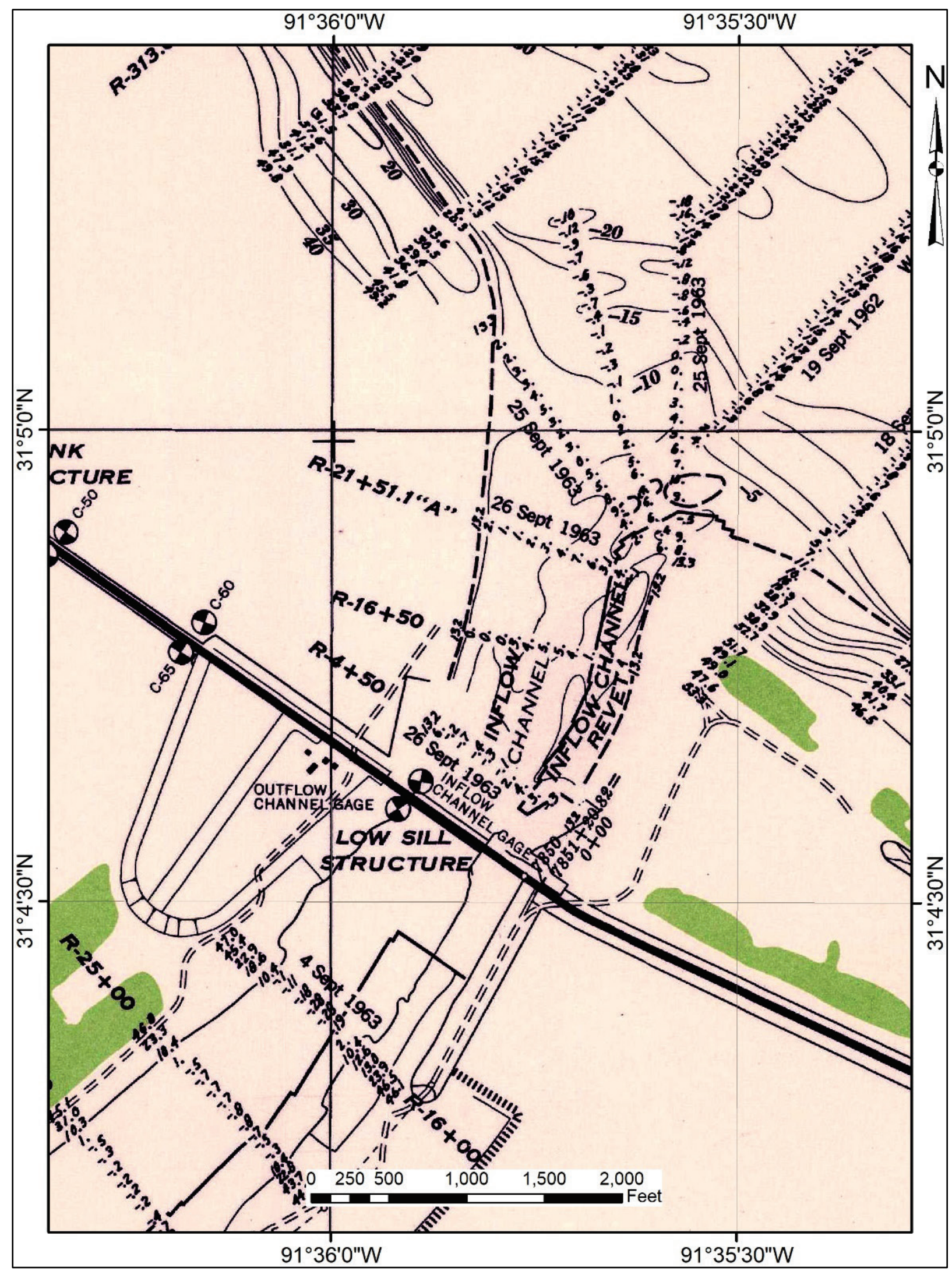

Figure 6. The ORLSS forebay area shown on a 1963 base map (USACE 1965). 


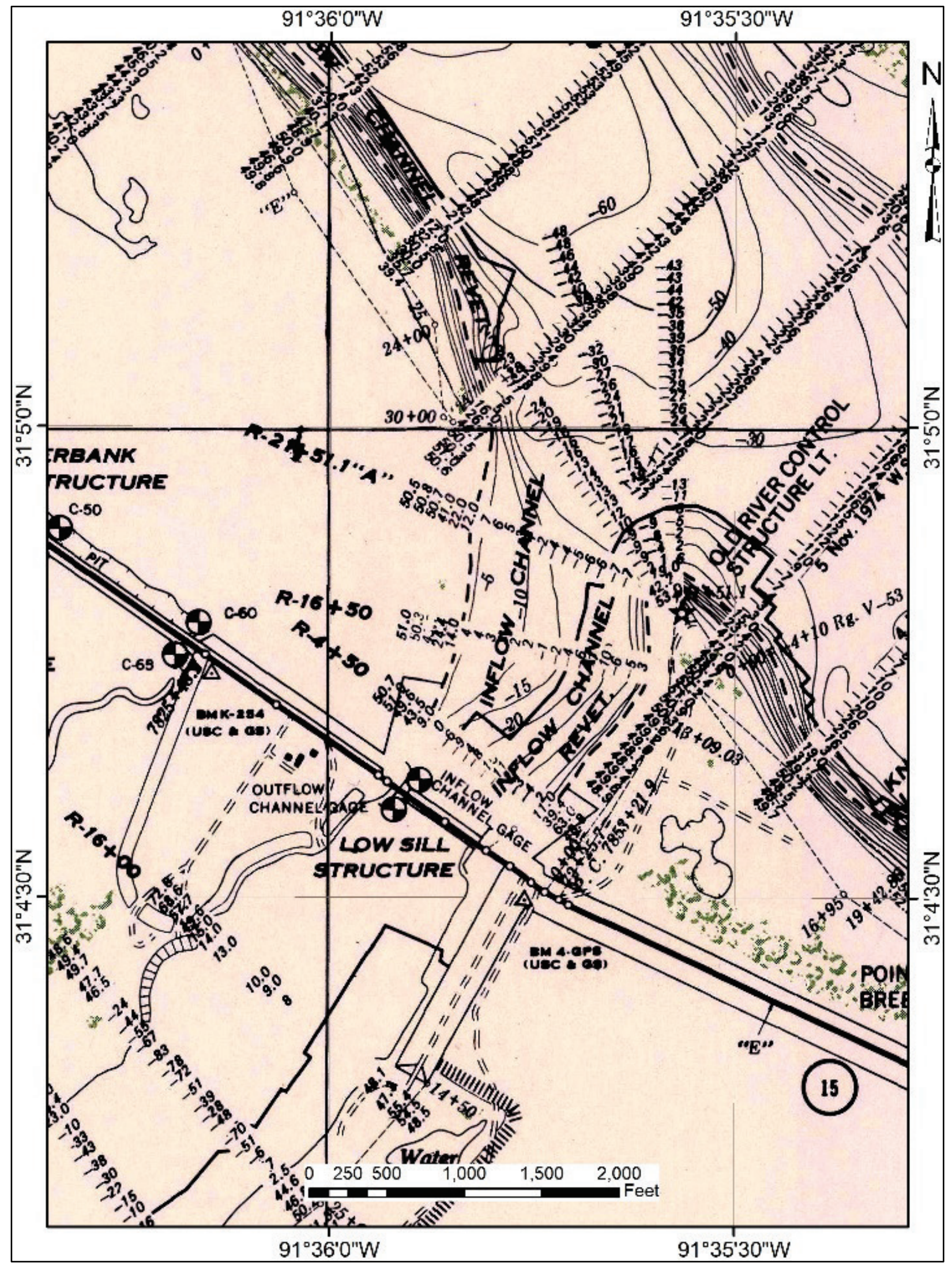

Figure 7. The ORLSS forebay area shown on a 1973 base map (USACE 1976). 


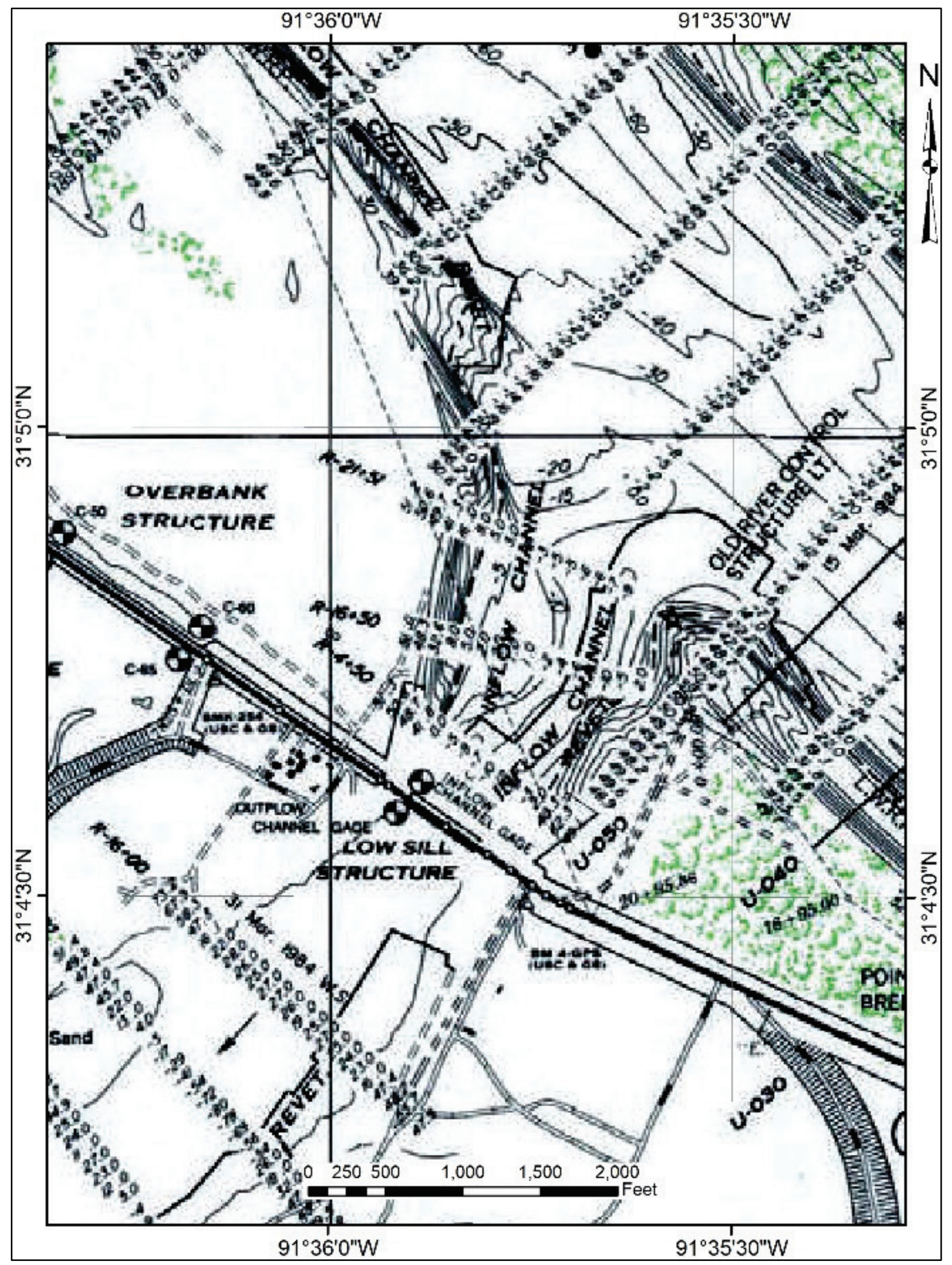

Figure 8. The ORLSS forebay area shown on a 1983 base map (USACE 1985). 


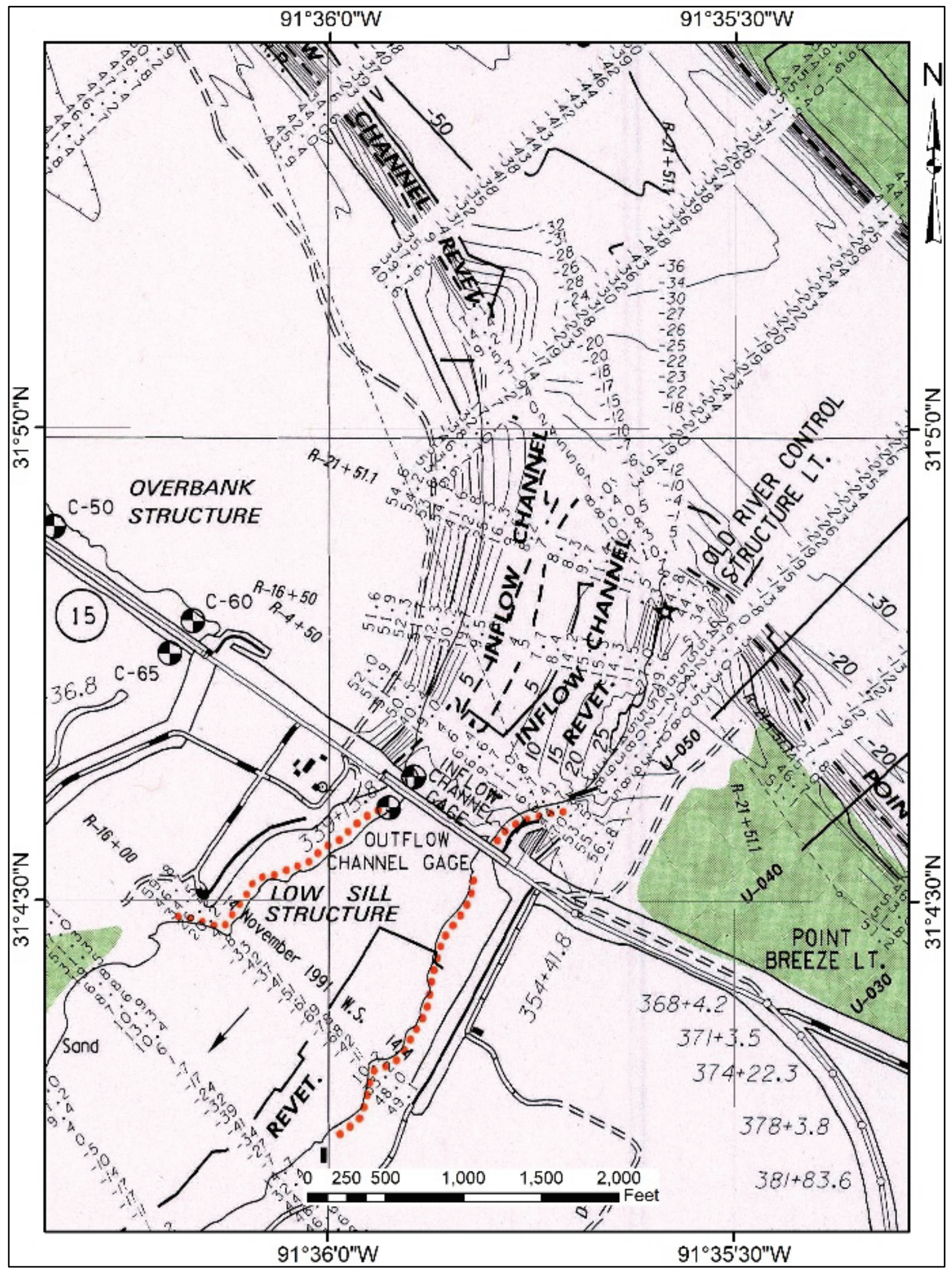

Figure 9. The ORLSS forebay area shown on a 1992 base map. (Note orange boundaries on map represent foreshore protection.) (USACE 1993). 


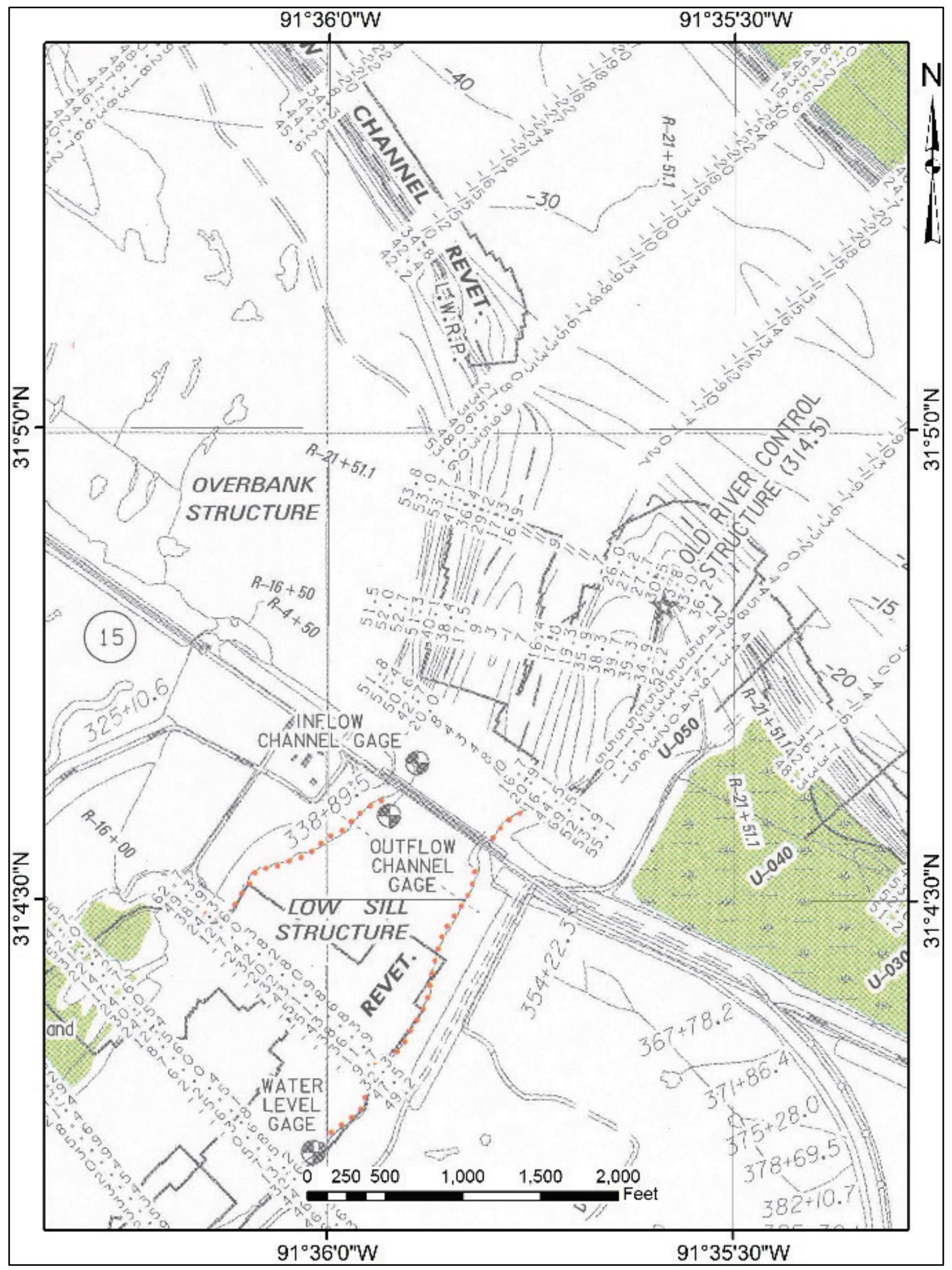

Figure 10. The ORLSS forebay area shown on a 2003 base map. (Note orange boundaries on map represent foreshore protection.) (USACE 2004). 


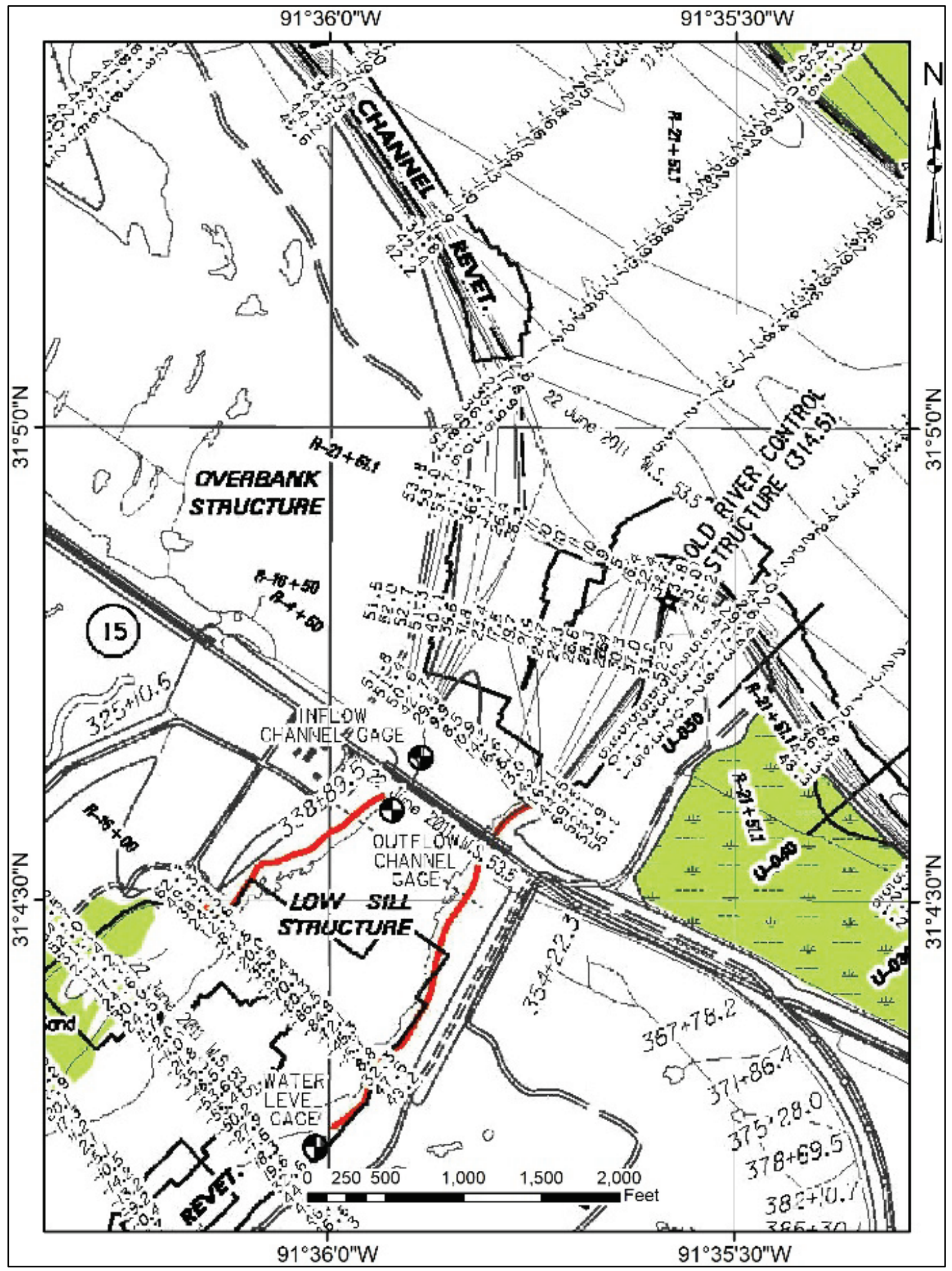

Figure 11. The ORLSS forebay area shown on 2013 base map. (Note orange boundaries on map represent foreshore protection.) (USACE 2013). 


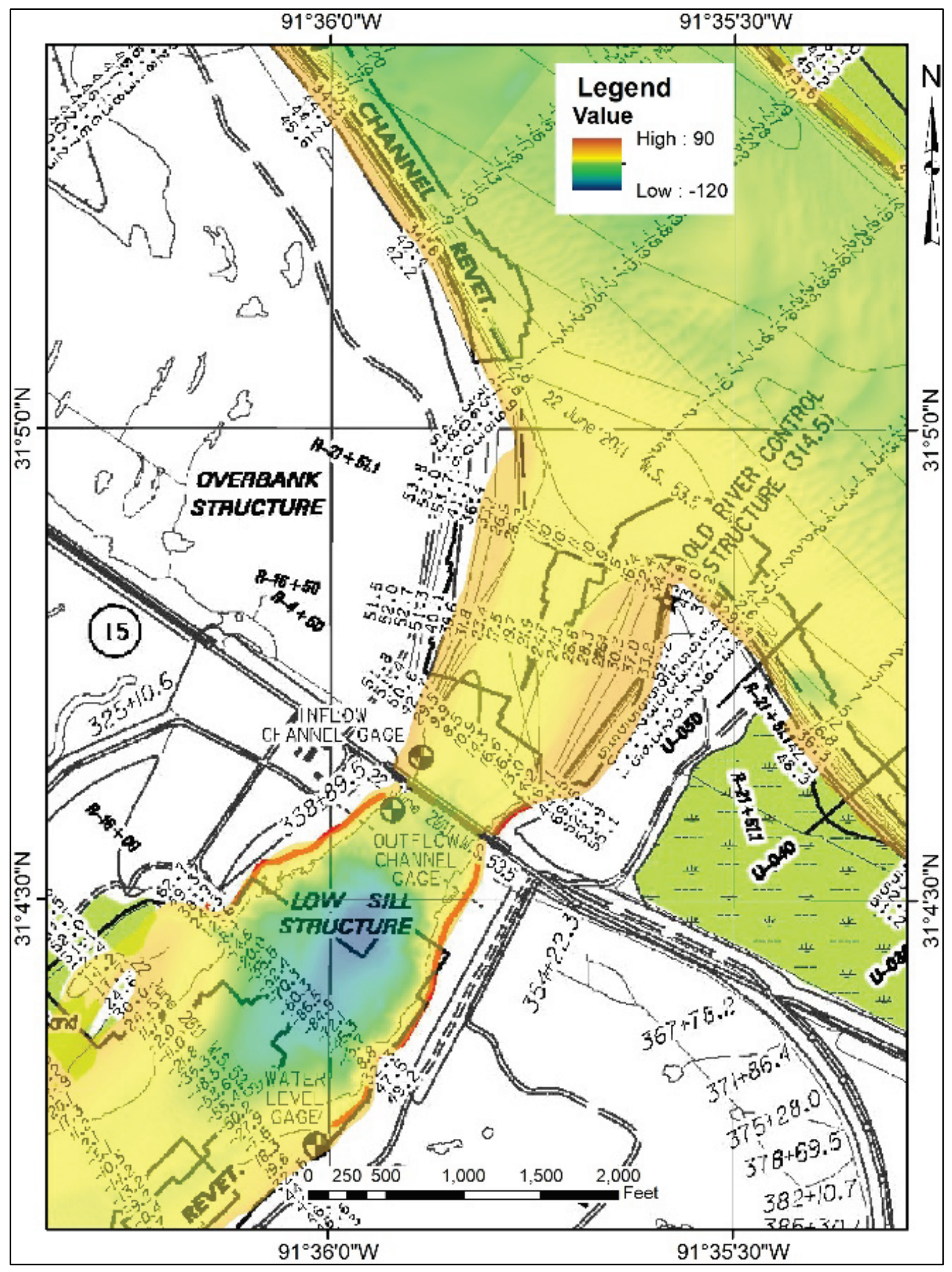

Figure 12. Grid from multi-beam and side-scan SONAR from 2016 over forebay area on 2013 base map. (Note orange boundaries on map represent foreshore protection.) (USACE 2013). 


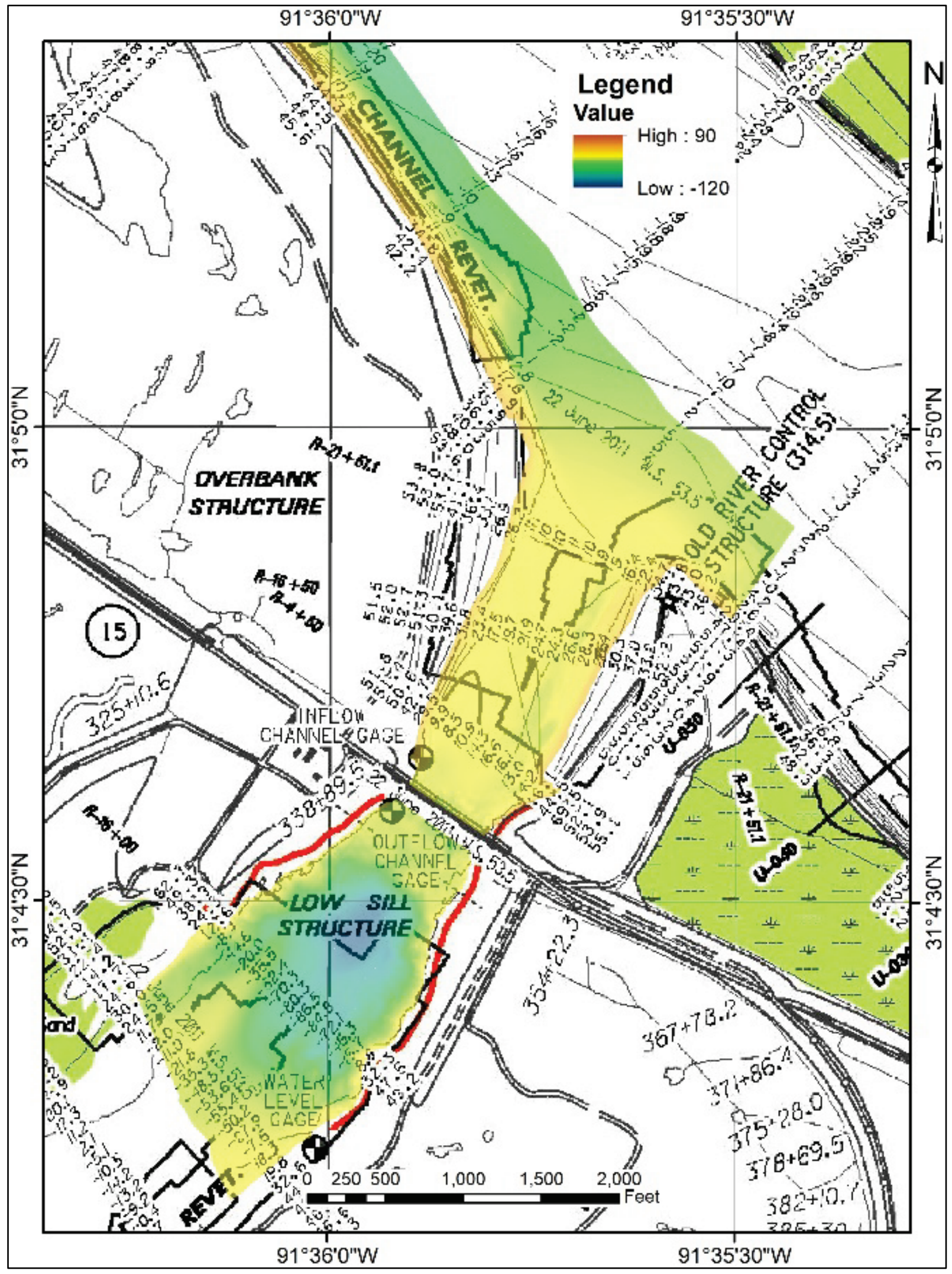

Figure 13. Grid from multi-beam and side-scan SONAR from 2019 over forebay area on 2013 base map. (Note orange boundaries on map represent foreshore protection.) (USACE 2013). 
PROFILE AND AREA GENERATION: Digital point data from each range line were extracted for each survey year to produce a profile of the channel cross section between the LWRP bank limits (Figure 14). For the years without a paper base map (i.e., 2016 and 2019), ArcMap's 3D Analyst extension was used to generate point data along range lines from the multi-beam side-scan SONAR data (Figures 12 and 13). Channel profiles for both point and grid data were produced using the ArcMap 3D Analyst extension and profile graph tools in this extension. These tools were used to transform elevation information in either point or raster format into a distance and elevation profile for each survey range line (Figure 14). Profile data were then copied into a Microsoft Excel spreadsheet for calculation of the channel area by an area tool function in Golden Software Grapher 15 (Figure 15).

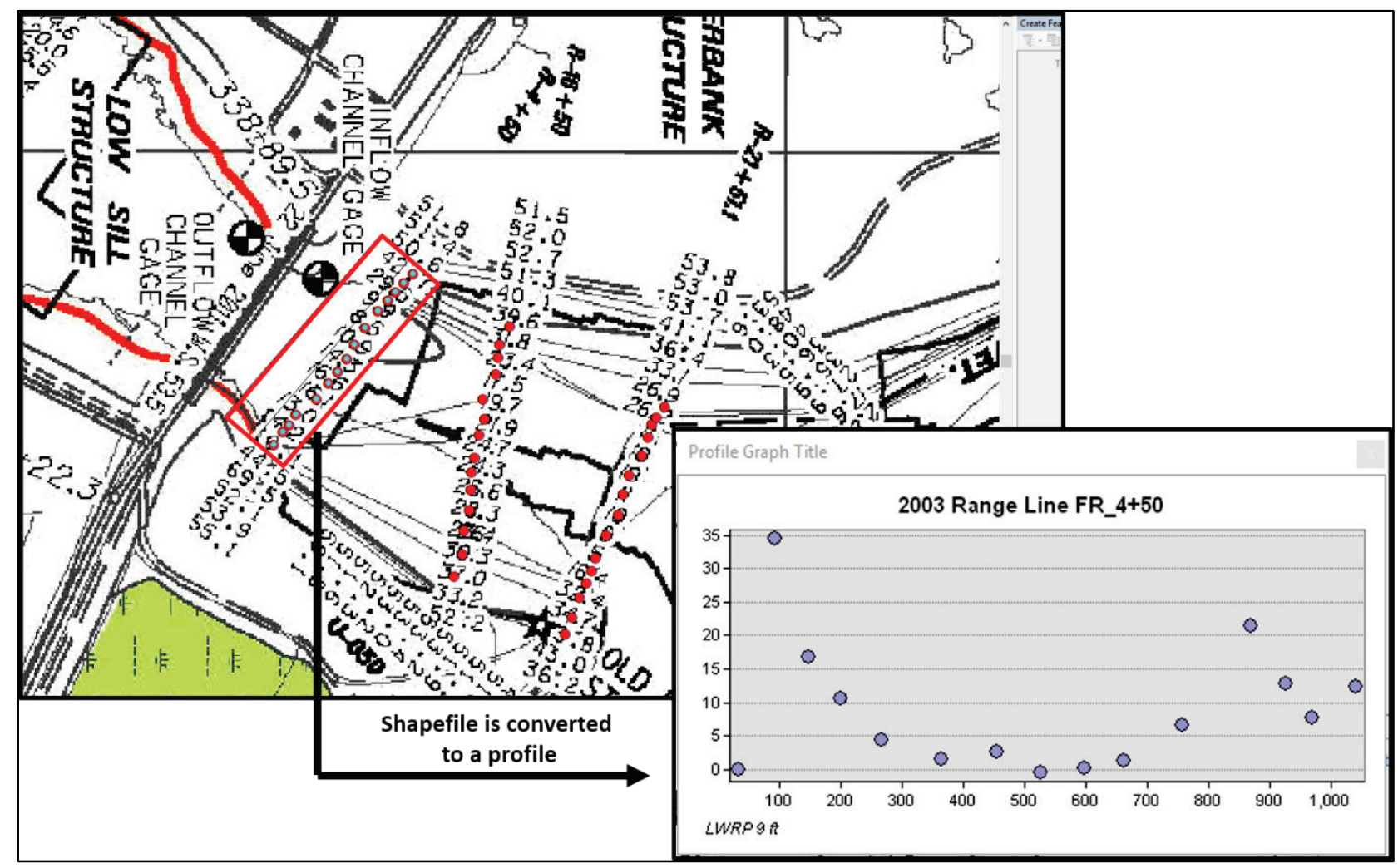

Figure 14. A range line profile is created using the 3D Analyst extension tools. Note that the survey range lines are named "FR" for Forebay Range when used in ArcMap. Depths and distances are calculated for the point data on the survey. Data points were evaluated for area under the LWRP using tools in Golden Software Grapher 15.

ArcMap's Measure tool was used to calculate the distance in feet across the LWRP channel for each range line in the profile (Figure 14). Both thalweg elevation and depth at each range line location were recorded from values identified on each survey sheet and/or the raster grid for the digital surveys. Depth data were derived from the reported values of the LWRP for each survey year. Profile tools in ArcMaps's 3D Analysts were a check on the range line distance for the LWRP derived by manual methods. This check required only the profile distance tool between the LWRP limits to be calculated in Excel by subtracting the excess profile distance outside the LWRP from the total length of the profile.

Information of interest to this study was the elevation for the LWRP for the respective hydrographic sheet, the datum for the survey, the width of the channel between the LWRP, the 
thalweg elevation (and depth), the width/depth ratio, and area beneath the LWRP channel. Figure 15 shows an image from Grapher 15 with the calculation of channel area for R 4+50 from the 2013 survey below the LWRP (elevation $14.5 \mathrm{ft}$ ). Forebay data obtained from the different hydrographic survey years examined are shown in Table 1.

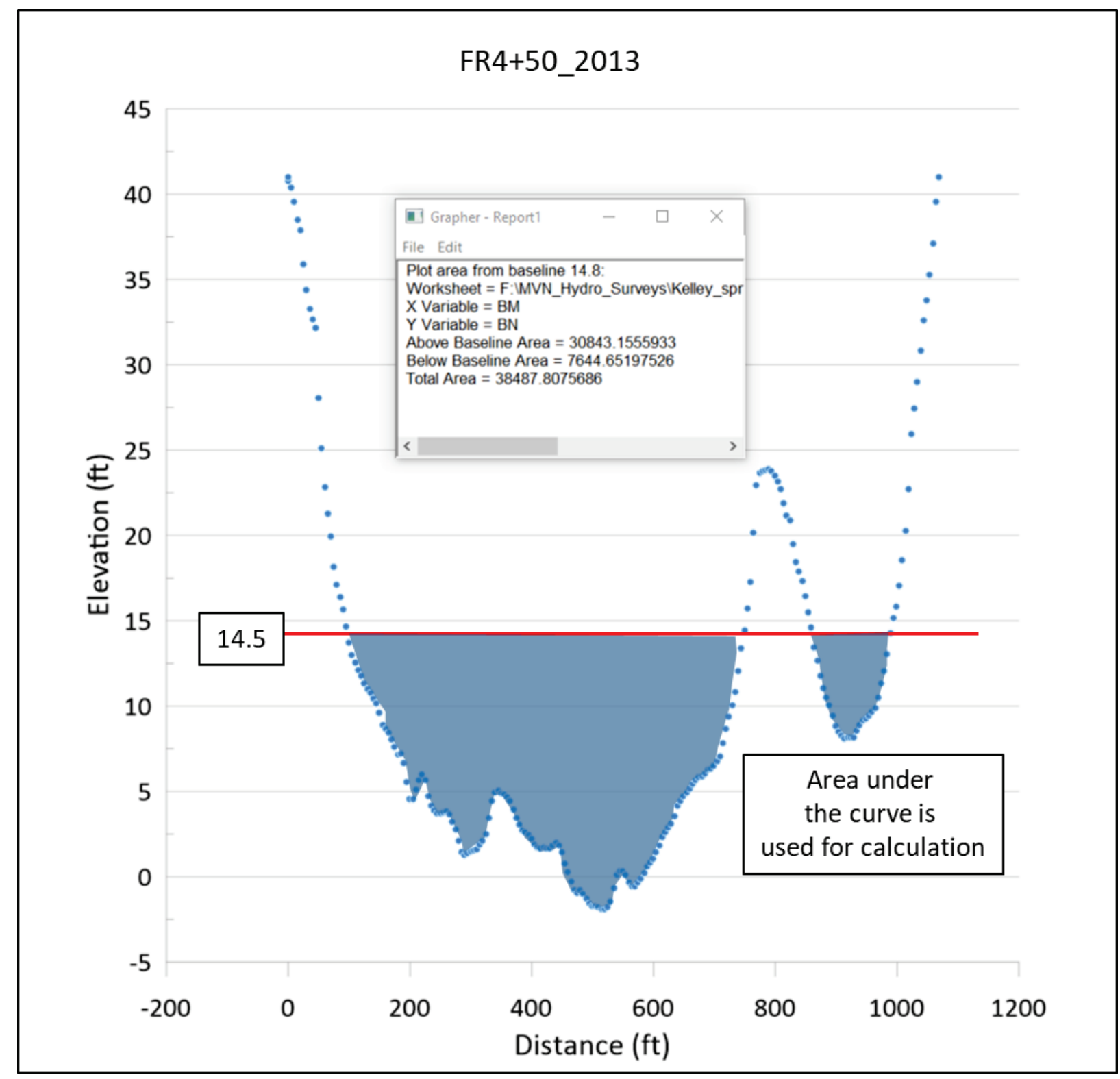

Figure 15. Calculation of channel area using Golden Software Grapher 15.

\section{RESULTS AND DISCUSSION}

The following discussion examines results of the hydrographic survey measurements (Table 1). Discussion focuses on the information topics contained in Table 1 in their order of presentation. 
LWRP: The vertical datum for the LWRP has changed with time as shown by Table 1 . The respective surveys have used mean sea level (MSL), National Geodetic Vertical Datum of 1929 (NGVD 29), and NAVD 88 for their reference. Standardization of the elevation datum for the different survey years was not made for this study. Variation in the LWRP elevation occurs because of the longitudinal profile of the Mississippi River, as the river's floodplain is a sloping surface to the Gulf of Mexico. Correction factors to normalize the different LWRP survey datums in the study area would require calibration to local benchmarks to normalize any differences that exist. There is a recognition here that the datum (and reported elevation) for the LWRP has changed with the different survey periods identified.

Table 1. Summary table of the three range lines over a period of 56 years.

\begin{tabular}{|c|c|c|c|c|c|c|c|c|}
\hline $\begin{array}{c}\text { Forebay Range } \\
\text { Number }\end{array}$ & Year & $\begin{array}{l}\text { Vertical } \\
\text { Datum }\end{array}$ & $\begin{array}{l}\text { LWRP } \\
\text { LA State } \\
\text { Plane (ft) }\end{array}$ & $\begin{array}{l}\text { Width } \\
\text { (ft) }\end{array}$ & $\begin{array}{c}\text { Depth } \\
\text { (ft) }\end{array}$ & ELV (ft) & W/D & $\begin{array}{l}\text { Area } \\
\left(\mathrm{ft}^{2}\right)\end{array}$ \\
\hline \multirow[t]{8}{*}{ FR_4+50 } & 1963 & MSL & 9 & 1101 & 9.7 & -0.7 & 114 & 9493 \\
\hline & 1973 & MSL & 12 & 1011 & 27 & -15 & 37 & 15995 \\
\hline & 1983 & NGVD 29 & 12 & 943 & 22 & -10 & 43 & 13789 \\
\hline & 1992 & NGVD 29 & 12 & 906 & 7.7 & 4.3 & 118 & 3184 \\
\hline & 2003 & NAVD 88 & 15 & 629 & 12 & 3 & 52 & 5036 \\
\hline & 2013 & NAVD 88 & 14.8 & 792 & 14 & 0 & 57 & 7019 \\
\hline & 2016 & NAVD 88 & 15 & 588 & 10.7 & 4.3 & 55 & 4336 \\
\hline & 2019 & NAVD 88 & 15 & 812 & 14.1 & 0.9 & 58 & 7797 \\
\hline \multirow[t]{8}{*}{ FR_16+50 } & 1963 & MSL & 9 & 1165 & 9 & 0 & 129 & 6785 \\
\hline & 1973 & $\mathrm{MSL}$ & 12 & 1269 & 22 & -10 & 58 & 16455 \\
\hline & 1983 & NGVD 29 & 12 & 1351 & 22 & -10 & 61 & 17437 \\
\hline & 1992 & NGVD 29 & 12 & 525 & 8.4 & 3.6 & 63 & 1892 \\
\hline & 2003 & NAVD 88 & 15 & 550 & 8.7 & 6.3 & 63 & 3499 \\
\hline & 2013 & NAVD 88 & 14.8 & 545 & 7.7 & 6.3 & 71 & 2886 \\
\hline & 2016 & NAVD 88 & 15 & 545 & 9.5 & 5.5 & 57 & 3429 \\
\hline & 2019 & NAVD 88 & 15 & 697 & 15.1 & -0.1 & 46 & 5974 \\
\hline \multirow[t]{8}{*}{ FR_21+51.1 "A" } & 1963 & MSL & 9 & 1232 & 8 & 1 & 154 & 5619 \\
\hline & 1973 & MSL & 12 & 1210 & 19 & -7 & 64 & 14817 \\
\hline & 1983 & NGVD 29 & 12 & 1365 & 21 & -9 & 65 & 14337 \\
\hline & 1992 & NGVD 29 & 12 & 1010 & 6.9 & 5.1 & 146 & 2670 \\
\hline & 2003 & NAVD 88 & 15 & 595 & 8 & 7 & 74 & 2608 \\
\hline & 2013 & NAVD 88 & 14.8 & 726 & 14 & 0 & 52 & 6901 \\
\hline & 2016 & NAVD 88 & 15 & 777 & 4.6 & 10.4 & 168 & 1889 \\
\hline & 2019 & NAVD 88 & 15 & 844 & 11.3 & 4.7 & 75 & 4425 \\
\hline
\end{tabular}


The LWRP has increased in elevation from $9 \mathrm{ft}$ in 1963 to $15 \mathrm{ft}$ in 2019 (Figure 16). This 6-ft increase has occurred over a time interval of $56 \mathrm{yr}$, corresponding to an increase of about $1 \mathrm{ft}$ every $10 \mathrm{yr}$. This general trend closely matches the observed gage data record shown in Figure 4.

If the increase in the LWRP value continues to rise as shown by Figure 16, then it is possible to estimate this increase for time periods of interest in the future. A common measure of the life expectancy of engineered structures is 100 years. Thus, if the trend in Figure 16 continues, the LWRP will rise an additional $4 \mathrm{ft}$ over the next 40 years. This trend would result in exceeding the 22 -ft restriction on head difference and has far-reaching consequences for river stages experienced at the ORLSS in the future.

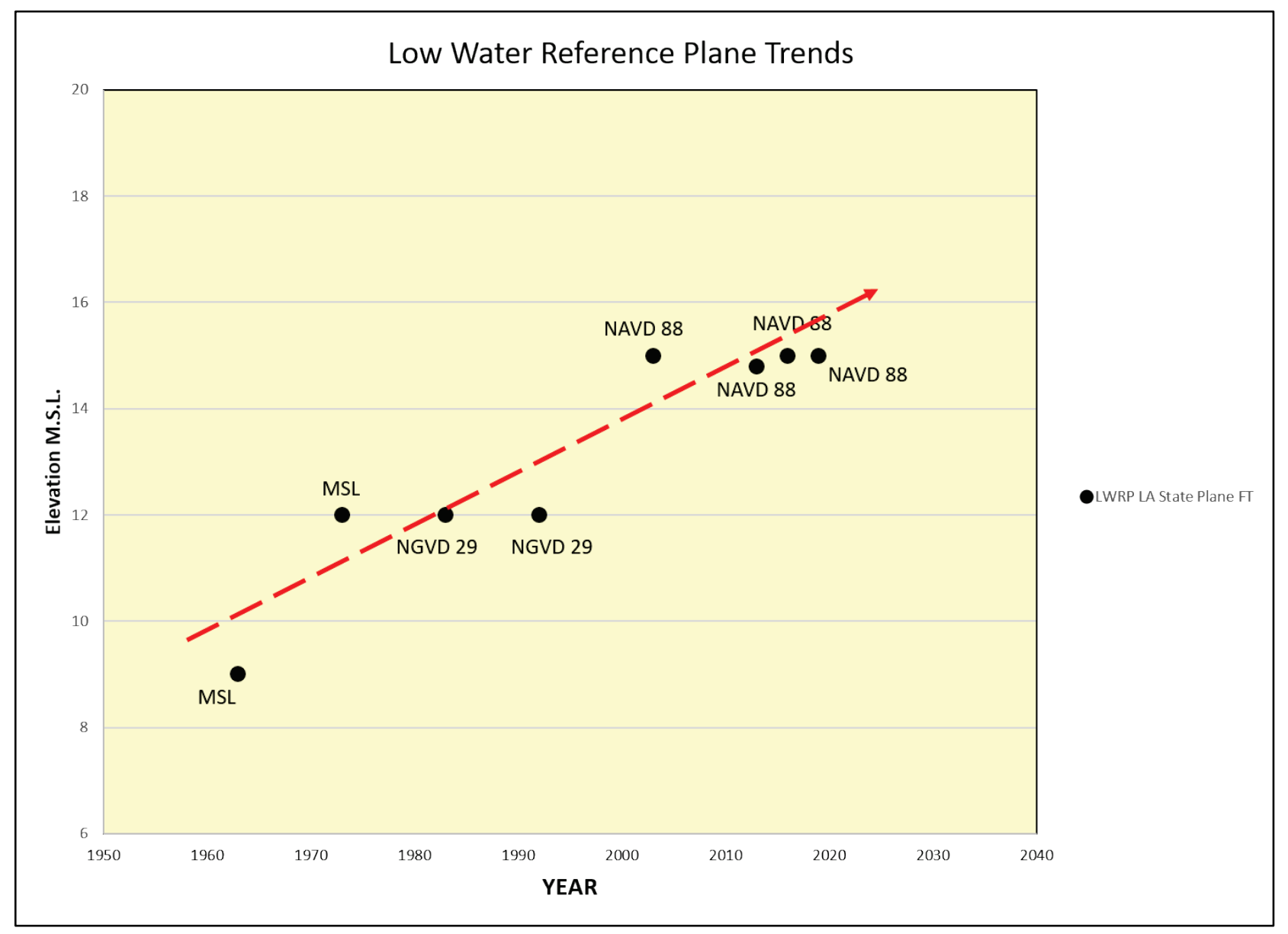

Figure 16. Trend in the LWRP from 1963 to 2019.

WIDTH: Results of channel width measurements in the forebay are shown in Figure 17. The width of the channel has decreased from its maximum extent between 1963 and 1993 to present-day widths between 700 and $850 \mathrm{ft}$. A major reduction occurred after 1993. Channel width is increasing in the middle and outer part of the forebay channel for the most recent survey.

DEPTH: Trends for thalweg depth are presented in Figure 18. Maximum values occur between 1973 and 1983 with values exceeding $18 \mathrm{ft}$. Depth declines to less than $15 \mathrm{ft}$ after 1993, with several survey years below $10 \mathrm{ft}$ near the Mississippi River. The 1963 survey shows the depth was less than $10 \mathrm{ft}$ 
after the structure was placed into service. The 2016 survey shows there was a slight decrease in depth, followed by an increase in 2019. The general trend since 1993 has been a depth between 7 and $15 \mathrm{ft}$. The profile nearest the Mississippi River has the maximum range between adjacent surveys. This variation is likely from maximum sedimentation and erosion episodes on the main channel.

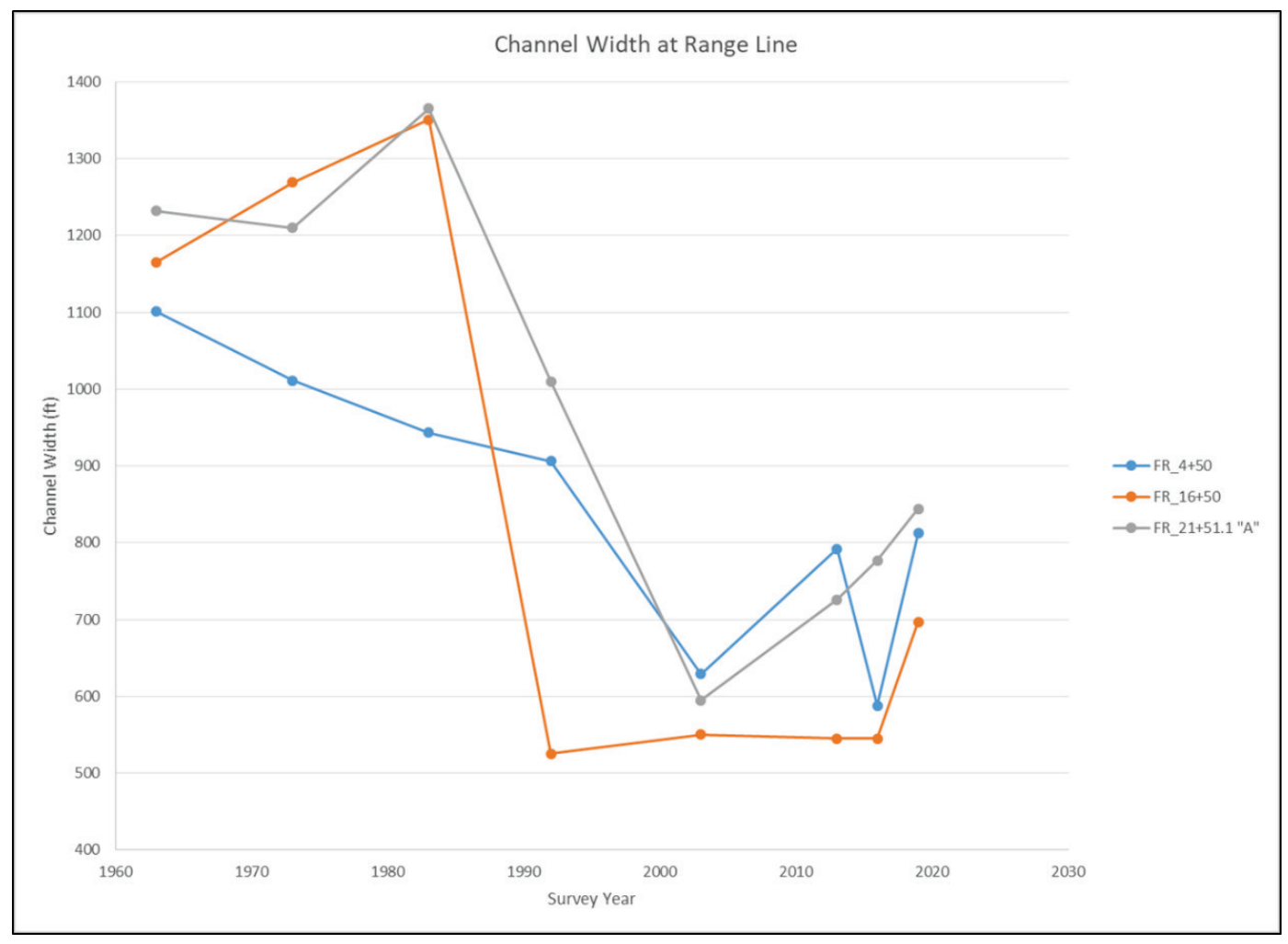

Figure 17. Forebay channel width has decreased over time. 
ERDC/GSL TN-21-1

September 2021

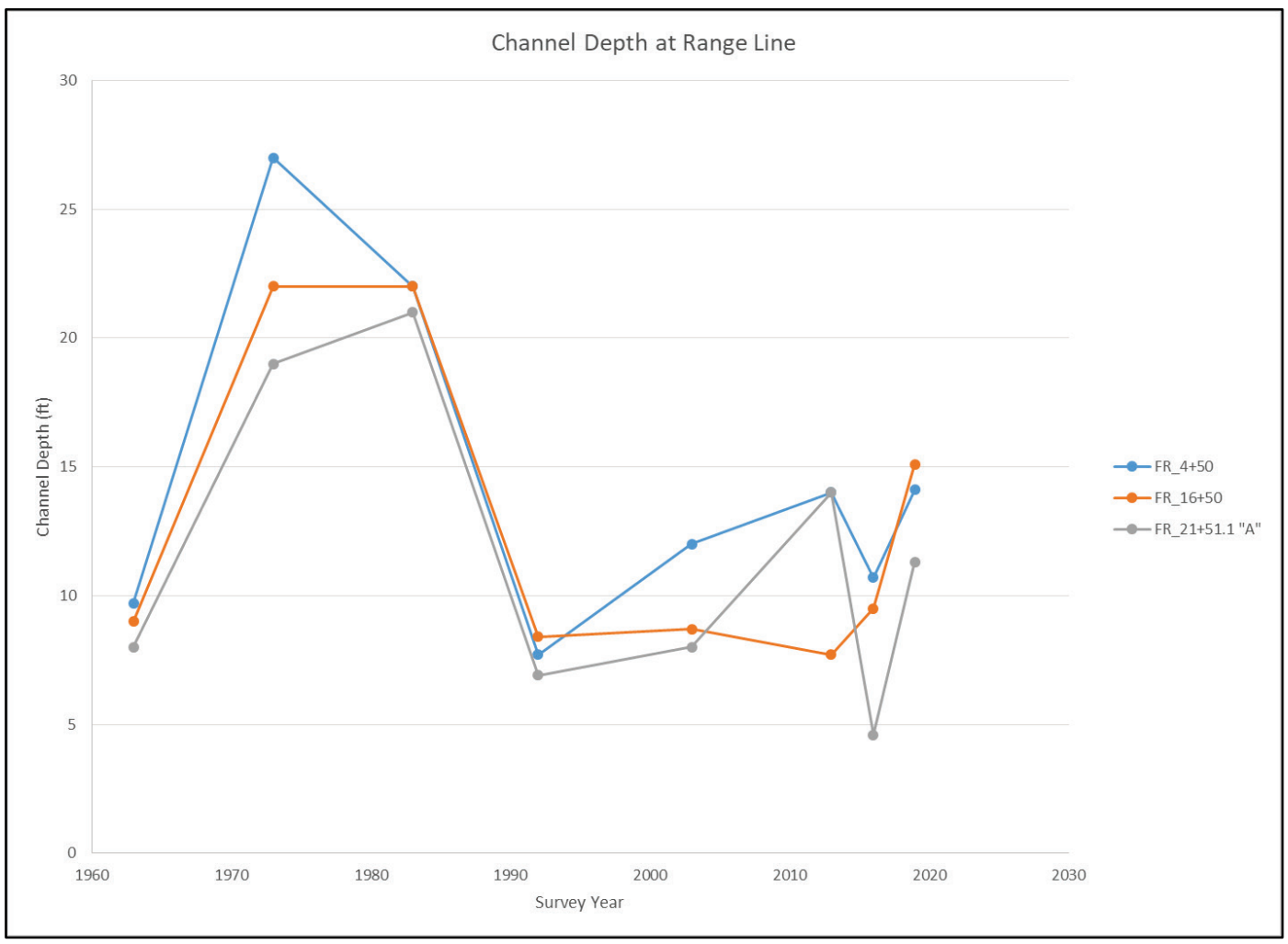

Figure 18. Forebay channel depth has decreased over time.

WIDTH AND DEPTH RATIO (W/D): A variable W/D ratio is shown by Figure 19 for the period of record. The large variation primarily reflects changes in channel depth, with larger W/D ratios corresponding to a relatively shallow channel depth. Significant changes occurred following the 1973 flood because of deep scouring in the forebay. Forebay range (FR) $16+50$ is the least variable with a nearly uniform W/D value after 1973. The other two profiles show maximum variability corresponding to periods of channel sedimentation (higher W/D values) and scouring (lower W/D values). Maximum variation occurs furthest from the structure, which indicates sensitivity to main channel flow events. 


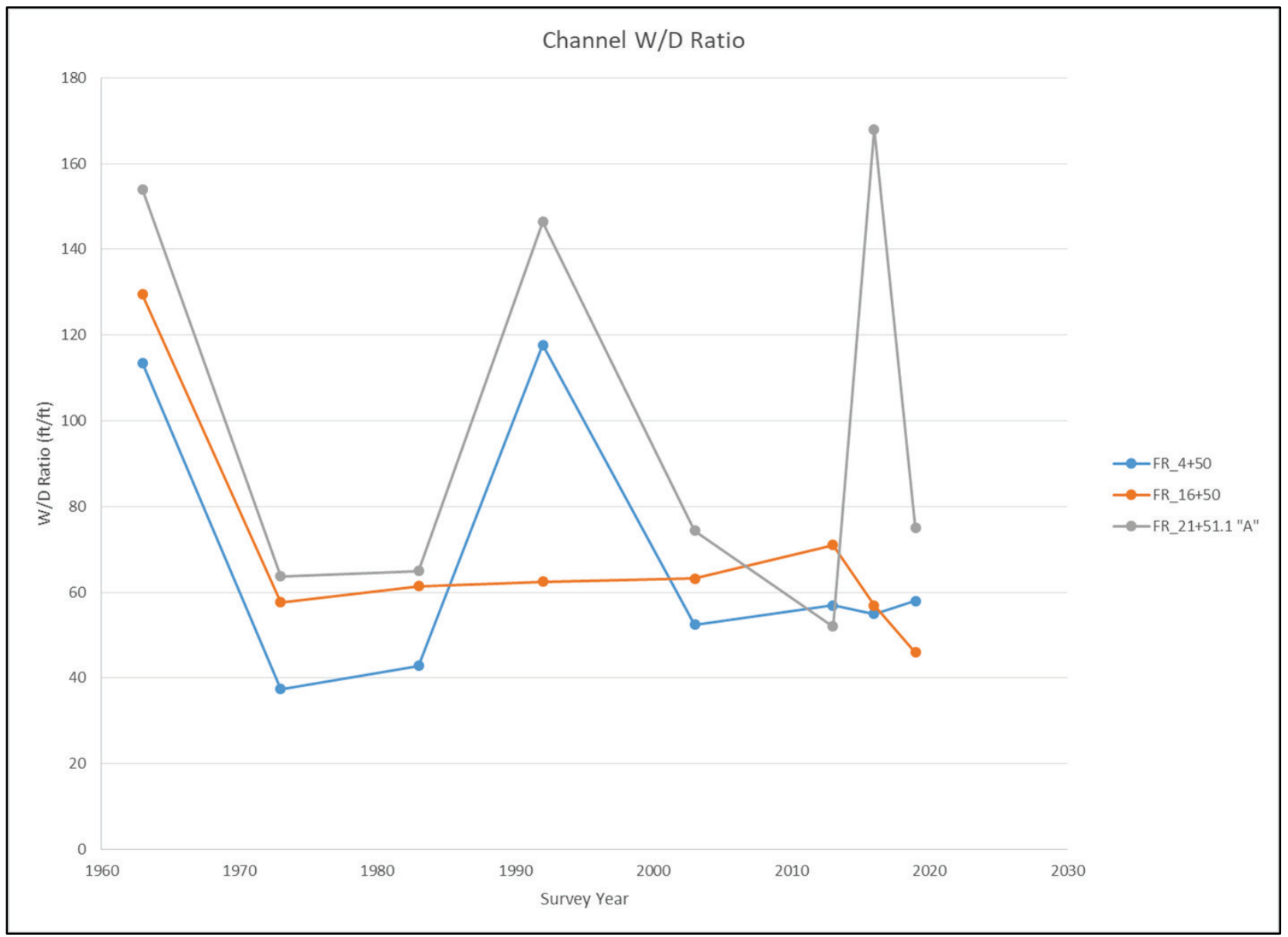

Figure 19. Channel Width/Depth ratio.

AREA: Channel area has significantly decreased after 1993 (Figure 20). Channel deepening occurred after the 1973 flood, combined with a wider channel, and resulted in maximum channel area below the LWRP. This trend continued in 1983 and sharply decreased in 1993, where the trend for a smaller (fixed) LWRP channel area had occurred. It bears mention here that this study did not look at channel geometry above the LWRP, which was not considered in these area calculations. The LWRP corresponds to normal flow conditions for most annual discharge conditions. 
ERDC/GSL TN-21-1

September 2021

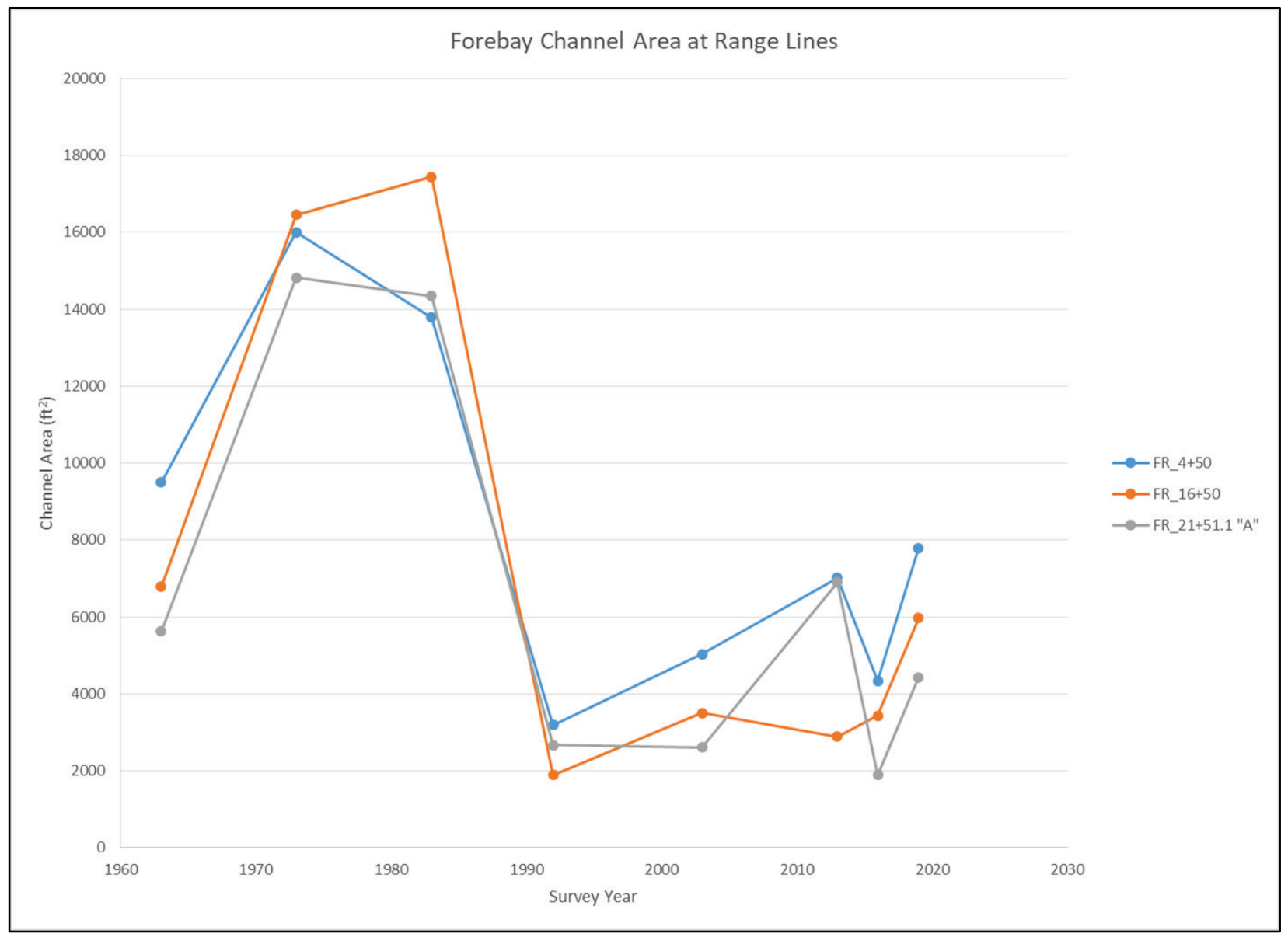

Figure 20. Forebay channel area at range lines.

REVETMENT HISTORY: An important component of a study of channel geometry involves the revetment history and hardening of the forebay banks. Figure 21 shows the spatial extent and year that revetment was placed and/or expanded in the forebay area. Additions of left bank revetment occurred in 1968, 1978, and 1981. Right bank revetment was placed in 1978. The absence of any recent bank protection indicates that the channel banks have been relatively stable, which is probably indicative of conditions observed after the 1993 survey. The LWRP channel area after 1993 is representative of a relatively stable bank regime, with deposition and scouring in the forebay primarily affecting the channel area values. 


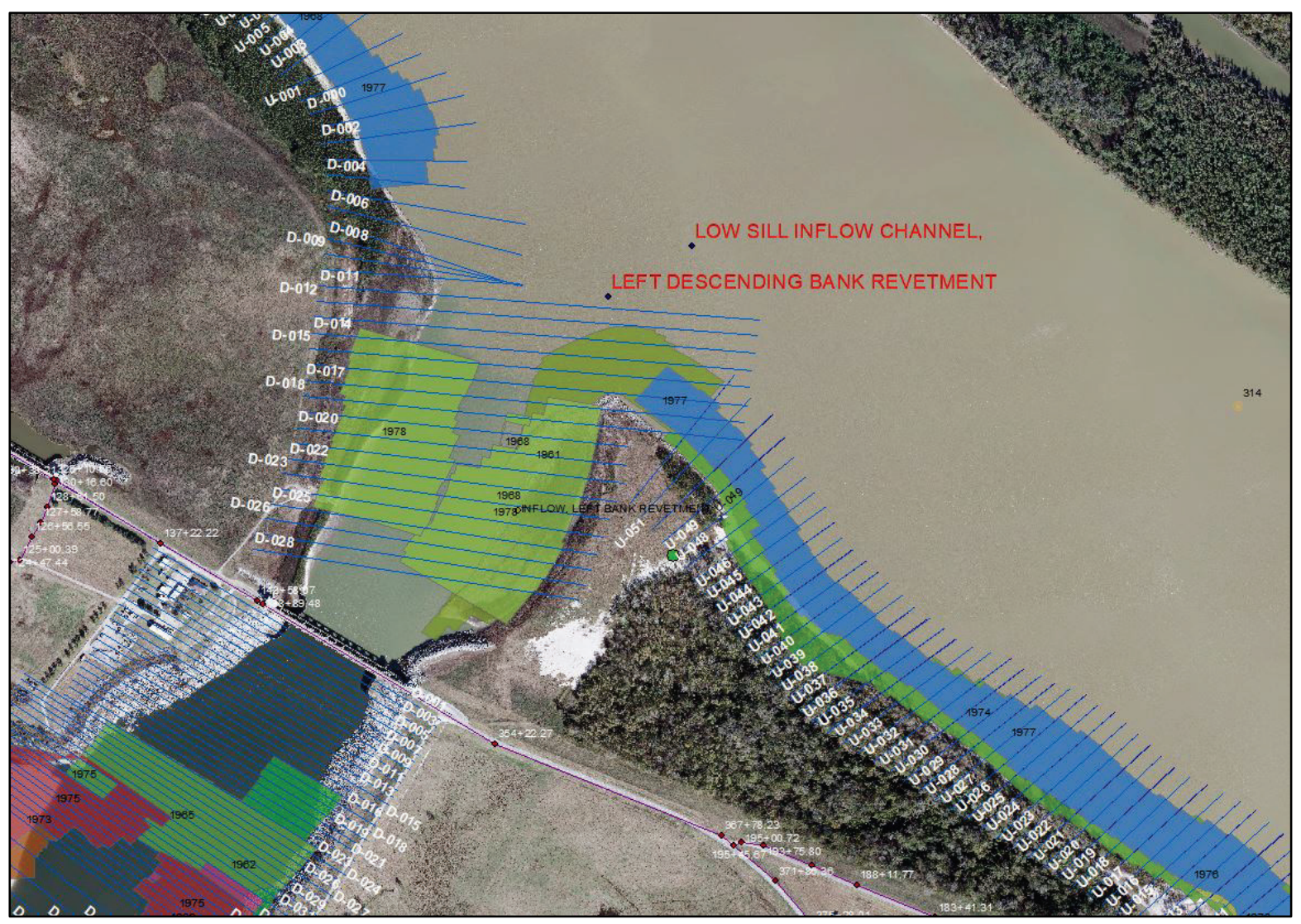

Figure 21. Revetment history in and around the ORLSS forebay area provided by Mr. M. Crawford ${ }^{4}, 2019$.

\section{CONCLUSIONS AND RECOMMENDATIONS}

CONCLUSIONS: Channel width, depth, and area below the LWRP in the ORLSS forebay area have decreased over time, with relatively stable bank and channel conditions occurring after 1993. Channel hardening with revetment last occurred in 1981 and indicates stable banks. Sedimentation and erosion in the forebay channel area have been variable since 1993, with channel depth experiencing the most dynamic change of 7 to $10 \mathrm{ft}$ of net difference between surveys. The bank elevation for the LWRP has risen $6 \mathrm{ft}$ during a nearly 60 -yr period of record and is predicted to be 4 $\mathrm{ft}$ higher over the 100-yr operating life of the structure, which is a common measure for life expectancy of engineered structures. Historic elevation changes observed in the LWRP value at ORLSS are consistent with similar elevation trends observed from gage data at Red River Landing (Biedenharn et al. 2017). Higher flood stages and an increasing LWRP elevation locally will result in an increased head differential on the structure in the future.

RECOMMENDATIONS: Changes observed in LWRP elevation in this study are based on different survey datums through time. Benchmark surveys at ORLSS are needed to resolve these datum differences to accurately compare elevation values obtained from the different historic surveys and future changes that can be expected.

\footnotetext{
${ }^{4}$ USACE MVN. 2019. Personal communication.
} 
The focus of this study was to identify changes in the forebay area over time. Researchers recommend an additional study to identify changes in the stilling basin over this time.

Periodic inspections identified a large scour hole before 1973 that is documented on issue specific hydrographic surveys. A study is recommended to compile and georeference these surveys for comparison of trends and changes in scour volume. This would lead to a better understanding of alluvial deposits affected and eventual migration beneath the structure during the 1973 flood.

POINT OF CONTACT: For additional information contact Julie Kelley (601-634-3551, Julie.R.Kelley@usace.army.mil).This technical note should be cited as follows:

\section{REFERENCES}

Biedenharn, D., A. Mead, C. Little, C. Thorne, and C. Watson. 2017. Large-scale geomorphic change in the Mississippi River from St. Louis, MO, to Donaldsonville, LA, as revealed by specific gage records. MRG\&P Technical Report No. 10. Vicksburg, MS: U.S. Army Corps of Engineers, Mississippi Valley Division.

Heath, R., G. Brown, C. Little, T. Pratt, J. Ratcliff, D. Abraham, N. Perkey, K. Ganesh, and D. Martin. 2015. Old river control complex sedimentation investigation. ERDC TR-15-8. Vicksburg, MS: U.S. Army Engineer and Development Center.

Hunter, C., M. Flanagin, and K. Marino. 2015. Mississippi River navigation book gets an updated low water reference plane. In Proceedings, ESRI International User Conference, July 14-18, San Diego.

U.S. Army Corps of Engineers (USACE). 1965. Mississippi River hydrographic survey, 1961-1963: Black Hawk, La. to Head of Passes, La., mile 0 to 324 (a.h.p.) and south and southwest Passes and Pass a Loutre. New Orleans: Mississippi River Commission.

. 1975a. Old river low sill and overbank structures, stability analysis, volume 1 text and appendixes. Design Memorandum No. 12. New Orleans: U.S. Army Corps of Engineers, New Orleans District.

1975b. Old river low sill and overbank structures, stability analysis, volume 2 plates. Design Memorandum No. 12. New Orleans: U.S. Army Corps of Engineers, New Orleans District.

1976. Mississippi River hydrographic survey, 1973-1975: Black Hawk, La. to Head of Passes, La., mile 0 to 324 (a.h.p.) and south and southwest Passes and Pass a Loutre. New Orleans: Mississippi River Commission.

. 1985. Mississippi River hydrographic survey, 1983-1985: Black Hawk, La. to head of Passes, La., and south and southwest Passes and Pass a Loutre. New Orleans: Mississippi River Commission.

1993. Mississippi River hydrographic survey, 1991-1992: Black Hawk, La. to head of Passes, La., and south and southwest Passes and Pass a Loutre." New Orleans: Mississippi River Commission.

2004. Mississippi River: Black Hawk, La. to Gulf of Mexico, mile 324 to mile 23 BHP: 2004 hydrographic survey. New Orleans: Mississippi River Commission.

2013. Mississippi River: Black Hawk, Louisiana, to the Gulf of Mexico, 2011-2013 hydrographic survey. New Orleans: Mississippi River Commission. 
ERDC/GSL TN-21-1

September 2021

NOTE: The contents of this technical note are not to be used for advertising, publication, or promotional purposes. Citation of trade names does not constitute an official endorsement or approval of the use of such products. 